\title{
State of the art in production, properties and applications of the microcrystalline sintered corundum abrasive grains
}

\author{
Krzysztof Nadolny
}

Received: 11 February 2014 / Accepted: 23 June 2014 / Published online: 3 July 2014

(C) The Author(s) 2014. This article is published with open access at Springerlink.com

\begin{abstract}
The following article presents the current state of knowledge about technologies connected with microcrystalline sintered corundum against the backdrop of present abrasive products and the contemporary grains market. The complementary presentation of issues related to the microcrystalline sintered corundum abrasive grains, which constitute an important group of abrasives used in modern grinding technology, was given. The most important stages in the development of sintered corundum grains production technology, from the 1960s to current developments (nanocrystalline sintered corundum) in this field, were presented in chronological order. The production technology, properties, working conditions, wear phenomena and most important areas of application of such abrasive grains were described. Particular attention was paid to the wear phenomena of microcrystalline sintered corundum abrasive grains occurring during the grinding process. The collection of phenomena affecting the extension of the life of these types of grain in comparison with the white fused alumina grains were described. Moreover, forecasts concerning the development of abrasive grains of micro- and nanocrystalline sintered corundum were presented.
\end{abstract}

Keywords Abrasive grains - Sintered corundum . Microcrystalline sintered corundum - Nanocrystalline sintered corundum . Sol-gel sintered alumina . Microcrystalline $\mathrm{Al}_{2} \mathrm{O}_{3}$

K. Nadolny $(\square)$

Department of Production Engineering, Faculty of Mechanical

Engineering, Koszalin University of Technology, Raclawicka 15-17,

75-620 Koszalin, Poland

e-mail: krzysztof.nadolny@tu.koszalin.pl

\section{Introduction}

Modern grinding processes guarantee highly machined surface quality, alongside increased machining efficiency. This is primarily achieved through the application of new abrasive materials, developing new kinematic variations and modifications of the grinding process parameters, or through the introduction of modifications in the grinding wheel structure (Fig. 1) [1-3]. These aspects are very often closely connected with each other, and for example, the effective realization of rough and finish grinding in a single working pass of the grinding wheel is connected with the proper modification of its structure $[4,5]$.

As the statistics concerning world production of abrasive grains show [6, 7], grains made from conventional materials, such as fused alumina $\left(\mathrm{Al}_{2} \mathrm{O}_{3}\right)$ and silicon carbide $(\mathrm{SiC})$, whose annual production amounts to 2,200,000 tonnes (Fig. 2a), are still the largest group of abrasives. The yearly production of so-called superhard abrasive grains, which includes natural and synthetic diamonds, as well as mono- and microcrystalline cubic boron nitride (cBN), is approximately 11,150 tonnes (Fig. 2b).

Super-hard machining using cBN abrasive grains has many advantages over conventional machining, especially in the grinding of difficult-to-cut steels and non-ferrous metals. The reduced wear of $\mathrm{cBN}$ grinding wheels makes it possible to reach high degrees of form and dimensional tolerance. In the case of steels which are difficult to cut, there is less influence on the workpiece surface layer because of the higher thermal conductivity of cubic boron nitride, resulting in a longer service life compared with grinding using conventional abrasives. Also, diamond has a very high heat conductivity in comparison with corundum or silicon carbide, but because of its chemical affinity, it cannot be used for grinding of ferrous materials [8-12]. 
Fig. 1 Main trends of development in grinding processes using grinding wheels

\begin{tabular}{|c|c|c|c|}
\hline \multicolumn{4}{|c|}{ Development trends in grinding processes } \\
\hline 1 & $t_{1}$ & 4 & I \\
\hline $\begin{array}{l}\text { New abrasive } \\
\text { materials, coatings } \\
\text { and shapes of } \\
\text { abrasive grains }\end{array}$ & $\begin{array}{c}\text { New kinematic } \\
\text { variation in grinding } \\
\text { processes }\end{array}$ & $\begin{array}{c}\text { Modification } \\
\text { of construction } \\
\text { of grinding wheels }\end{array}$ & $\begin{array}{l}\text { Other } \\
\text { trends }\end{array}$ \\
\hline $\begin{array}{l}\text { Microcrystalline } \\
\text { corundum grains } \\
\text { sintered in } \\
\text { Sol-Gel process } \\
\text { - Sintered corundum } \\
\text { grains of atypical } \\
\text { shape (TG, TGP, } \\
\text { SGP, SGA, SGB, } \\
\text { SGG, SGR) } \\
\text { - Alumina bubble } \\
\text { corundum grains } \\
\text { - Coated abrasive } \\
\text { grains } \\
\text { - Aggregate } \\
\text { abrasive grains } \\
\text { - etc. }\end{array}$ & $\begin{array}{l}\text { High-Speed } \\
\text { Grinding (HSG) } \\
\text { - High-Efficiency } \\
\text { Deep Grinding } \\
\text { (HEDG) } \\
\text { - Speed Feed } \\
\text { Grinding (SFG) } \\
\text { - Speed Stroke } \\
\text { Grinding (SSG) } \\
\text { Continous } \\
\text { Path-Controlled } \\
\text { Grinding (CPCG) } \\
\text { - Traverse Grinding, } \\
\text { Peel grinding } \\
\text { - etc. }\end{array}$ & $\begin{array}{l}\text { Grinding wheels with } \\
\text { mixed abrasive grains } \\
\text { Macrodiscontinuities } \\
\text { of the grinding wheel } \\
\text { Grinding wheels } \\
\text { impregnated with } \\
\text { anti-adhesion agents } \\
\text { Grinding wheels } \\
\text { with zone-diversified } \\
\text { structure } \\
\text { Microdiscontinuities } \\
\text { of active surface of } \\
\text { the grinding wheel } \\
\text { Grinding wheels } \\
\text { with internal } \\
\text { cooling system } \\
\text { etc. }\end{array}$ & $\begin{array}{l}\text { - Ultrasonic Grinding } \\
\text { - Vibration Grinding } \\
\text { - Vacuum Grinding } \\
\text { - Dry Grinding } \\
\text { - Cryogenic } \\
\text { Grinding } \\
\text { - Abrasive } \\
\text { Electro-Discharge } \\
\text { Grinding } \\
\text { Abrasive } \\
\text { Electro-Chemical } \\
\text { Grinding } \\
\text { etc. }\end{array}$ \\
\hline
\end{tabular}

Comparing amounts from Fig. 2, it can be observed that despite the increased popularity of machining using tools made from super-hard abrasive grains, they are only approximately $0.05 \%$ of the world production of abrasives.

Approximately $60 \%$ of all produced corundum types are applied as abrasives [13]. The remaining part of production of fused aluminium oxide is applied mostly in the further production of high-class fire-resistant products for foundries, as well as the steel and glass industries [14].

The largest group among abrasive products produced from abrasive grains are bonded tools (such as grinding wheels and abrasive segments), whilst coated abrasives (such as abrasive papers and canvas, as well as the discs and flap discs made from them) are produced in smaller quantities. Abrasive grains destined for machining with loose abrasives are less frequently produced (Fig. 3).

The presented market analyses show that the dominant group are bonded tools made from conventional abrasive

Fig. 2 World production of abrasive grains: a production capacity of conventional abrasives in 2011 [7]; b structure of production capacity of superhard abrasives in 2008 [6] a)

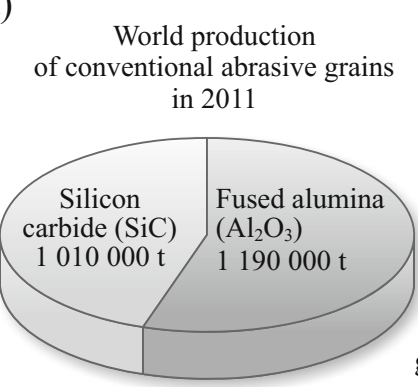

Altogether: 2,200,000 t grains, mostly from synthetic corundum found in a variety of fused alumina forms or sintered corundums.

In view of the above, modern varieties of conventional abrasive grains, especially abrasives from $\mathrm{Al}_{2} \mathrm{O}_{3}$, should be expected to be used more and more often. The most important of these are microcrystalline sintered corundum grains whose trade names are as follows: $\mathrm{SG}^{\mathrm{TM}}$, $\mathrm{SG}^{\mathrm{TM}}$, $\mathrm{SGB}^{\mathrm{TM}}$, $\mathrm{SGG}^{\mathrm{TM}}$, $\mathrm{SGR}^{\mathrm{TM}}, \mathrm{SGX}^{\mathrm{TM}}, \mathrm{TG}^{\mathrm{TM}}, \mathrm{TG}^{\mathrm{TM}}, \mathrm{TGP}^{\mathrm{TM}}, \mathrm{TGX}^{\mathrm{TM}}, \mathrm{XG}^{\mathrm{TM}}$ (Saint Gobain Abrasives-Norton), Cubitron ${ }^{\mathrm{TM}}$, Cubitron $321^{\mathrm{TM}}$, Cubitron $324^{\mathrm{TM}}$, Cubitron $421^{\mathrm{TM}}$ and Cubitron $\mathrm{II}^{\mathrm{TM}}$ (Minnesota Mining \& Manufacturing-3M) and Sapphire Blue $^{\mathrm{TM}}$ (Hermes Schleifmittel) [8-12, 16-22].

Microcrystalline sintered corundum belongs to the family of abrasive materials built from crystalline $\mathrm{Al}_{2} \mathrm{O}_{3}$ (corundum) and a low amount of dopes. The most popular abrasive in this group is fused alumina (also known as electrocorundum) which is obtained during the process of melting bauxite or aluminium oxide in resistance-arc furnaces $[8,9,11,12,20]$.

b)

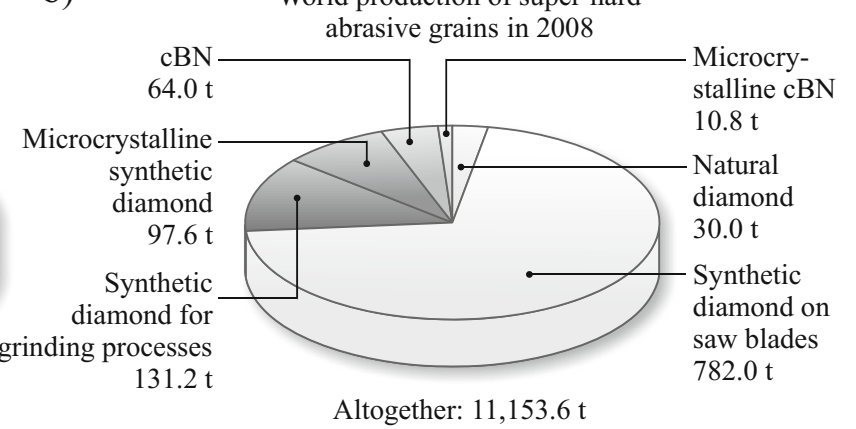


Fig. 3 Market structure of abrasive products between the years 1997 and 2005 [15]

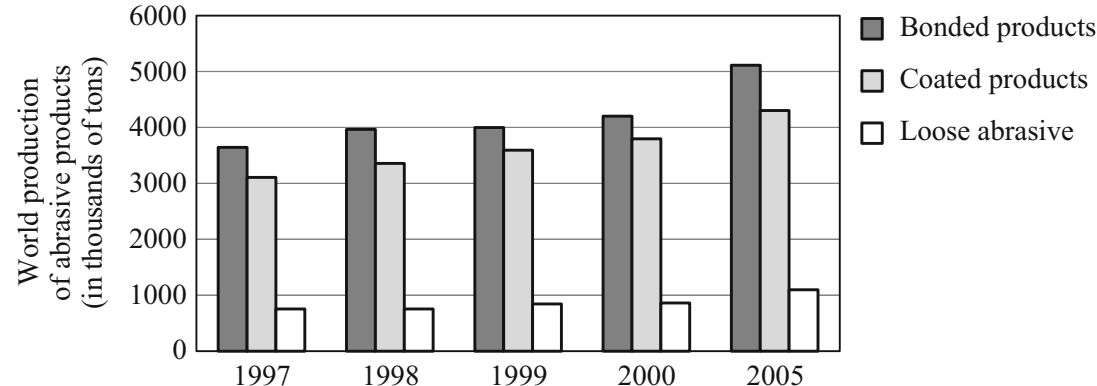

There are two types of fused alumina depending upon oxide content $\left(\mathrm{TiO}_{2}, \mathrm{SiO}_{2}, \mathrm{Fe}_{2} \mathrm{O}_{3}, \mathrm{CaO}, \mathrm{MgO}\right.$ and $\left.\mathrm{Na}_{2} \mathrm{O}\right)$ : brown fused alumina (BFA) and white fused alumina (WFA). Moreover, special fused alumina varieties are produced such as chromic, titanium and zirconic corundum, as well as monocorundum and sintered or spherical corundum (also known as bubble corundum) $[8,9,11,12,20]$.

The main objective of the paper is the complementary presentation of issues related to the microcrystalline sintered corundum abrasive grains, which today constitute an important group of abrasives used in modern grinding technology. Moreover, it can be assumed that in the future, the applications for such abrasives formed from micro- and nanocrystalline alumina oxide will dynamically expand, because of their affordable price and their greater efficacy within the grinding process, particularly compared with white fused alumina.

\section{Sintered corundum}

The sintered corundum production technology was developed in 1963 by the Norton company [23]. It consists of a concentrated slurry of fine-grained bauxite, granulation to the desired grain size and sintering in $1,600^{\circ} \mathrm{C}$. This technology offers the possibility of forming cylindrical, prismatic or cannular sintered rods from crystallites sized 1 to $5 \mu \mathrm{m}$. Figure 4 presents a view of zirconic sintered corundum.
Sintered corundum abrasive grains were marked as 76A, whilst the grinding wheels made from them are used mainly in rough and high-efficiency grinding processes within the mining industry, at speeds of up to $80 \mathrm{~m} / \mathrm{s}$.

\section{Microcrystalline sintered corundum}

The 1980s witnessed intensive works on a new generation of sintered corundum characterized by microcrystalline, or even submicrocrystalline, structure. In 1981, the 3M company (Minnesota Mining \& Manufacturing) developed an abrasive from microcrystalline sintered corundum under the trade name of Cubitron ${ }^{\mathrm{TM}}$, which was used in disc grinding wheels. It was a chemically precipitated and sintered material characterized by a multiphase composite structure [25-29]. The meaning of this material for abrasive grinding was, however, noticed a few years later when the Norton company patented the abrasive material called SGTM in 1986. It was microcrystalline sintered corundum produced using the sol-gel technology, sintering sub-micron-powder $\mathrm{Al}_{2} \mathrm{O}_{3}$, known from processes used to produce special ceramics [30]. The grain shape and proportions could be controlled by extruding slurry. The microcrystalline sintered corundum abrasive grains are also produced by the Hermes Schleifmittel company, under the trade name Sapphire Blue ${ }^{\mathrm{TM}}$ [8-12, 16-22].

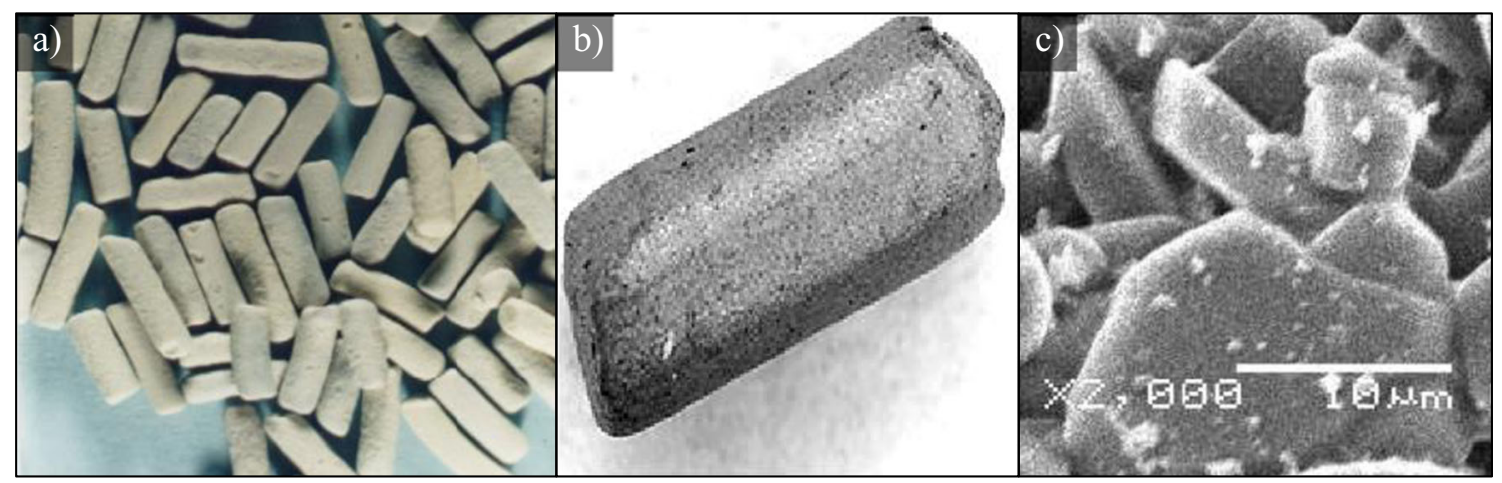

Fig. 4 Zirconic sintered corundum abrasive grains: a overall view-magnification $\times 4$; $\mathbf{b}$ abrasive grain magnitude $\times 40$; $\mathbf{c}$ microstructure of the abrasive grain-magnification $\times 2,000[24]$ 


\subsection{Production of microcrystalline sintered corundum grains}

Microcrystalline sintered corundum grains are produced in a chemical process in which microcrystalline alumina oxide, acquired using the expensive sol-gel technology, is sintered [8, 10-12, 20, 25-28]. Figure 5 presents the stages of production of microcrystalline sintered grains with the described method.

The initial material is boehmite $(\gamma-\mathrm{ALOOH})$, previously synthesized during the process of hydrolysis of alumina aloxite. The boehmite, obtained in this way, is characterized by a high degree of cleanness, a large absolute surface $\left(200-300 \mathrm{~mm}^{2} / \mathrm{g}\right)$ and small-sized particles $(5 \mathrm{~nm})$ [10, 29]. Next, water is added to powdered boehmite and it is mixed with it with the addition of a peptizing substance (usually nitric acid) to obtain a colloidal solution of boehmite particles dispersed in fluid and called sol (if water is the liquid, then it is called hydrosol). Next, nitric acid, or a nitrate solution, is added to sol in order to obtain gel through dehydration and polymerization. The nitric acid is, on the one hand, used as a peptizer in the creation of sol and, on the other, to form gel. This proves how important the relation of the added components volume (water, acid and boehmite) is in the sol-gel process [10].

As a result of gelation, boehmite is evenly dispersed in the obtained mass which is then dried and rolled at a temperature of approximately $80-100{ }^{\circ} \mathrm{C}$. The fragile dough obtained in this way is fragmented so that it can be sieved and separated into grain factions of the desired size at later stages of the process. At this level, the grains still contain alumina hydroxide in the boehmite phase. Next, the grains undergo initial heat processing at a temperature of $450-550{ }^{\circ} \mathrm{C}$, during which the alumina hydroxide is transformed into a temporary phase
$\gamma-\mathrm{Al}_{2} \mathrm{O}_{3}$. Nitrogen is released, as residues of acid and water, in the reaction between the boehmite and $\mathrm{z} \gamma-\mathrm{Al}_{2} \mathrm{O}_{3}$. This lowtemperature roasting is marked in Fig. 5 as calcination.

The last stage of production of microcrystalline sintered grains is atmospheric sintering during which the temperature is systematically increased until it reaches $1,200-1,500{ }^{\circ} \mathrm{C}$ [10]. The obtained material is then sieved and sorted into particular grain sizes in accordance with the norms (ISO, FEPA) [31-33].

\subsection{Properties of microcrystalline sintered corundum grains}

Microcrystalline sintered corundum is characterized by similar hardness and greater ductility than fused alumina oxide grains, which translates into a greater resistance to brittle fracture [34]. Figure 6 presents a comparison of abrasive and cutting materials' resistance to brittle fracture, as well as their hardness.

The next images present microscopic views of $\mathrm{SG}^{\mathrm{TM}}$, Cubitron $321^{\mathrm{TM}}$ and Sapphire Blue ${ }^{\mathrm{TM}}$ grains (Fig. 7), as well as SEM images of the $\mathrm{SG}^{\mathrm{TM}}$ grain microstructure produced by the Norton company (Fig. 8).

Compared to white fused alumina, microcrystalline sintered corundum grains are about $5 \%$ harder (Table 1). Their shape is similar to the standard form of white fused alumina but is characterized by greater uniformity of shape and size. The grains are composed of a large number of minor crystallites, connected through a thin crystalline layer (Fig. 8b) [34].

As the grains of white fused alumina are characterized by a polycrystalline structure, with preferential crystallographic planes, they crack parallel to these planes (according to the
Fig. 5 Basic representation of the sol-gel sintered corundum manufacturing process $[10,27,28]$

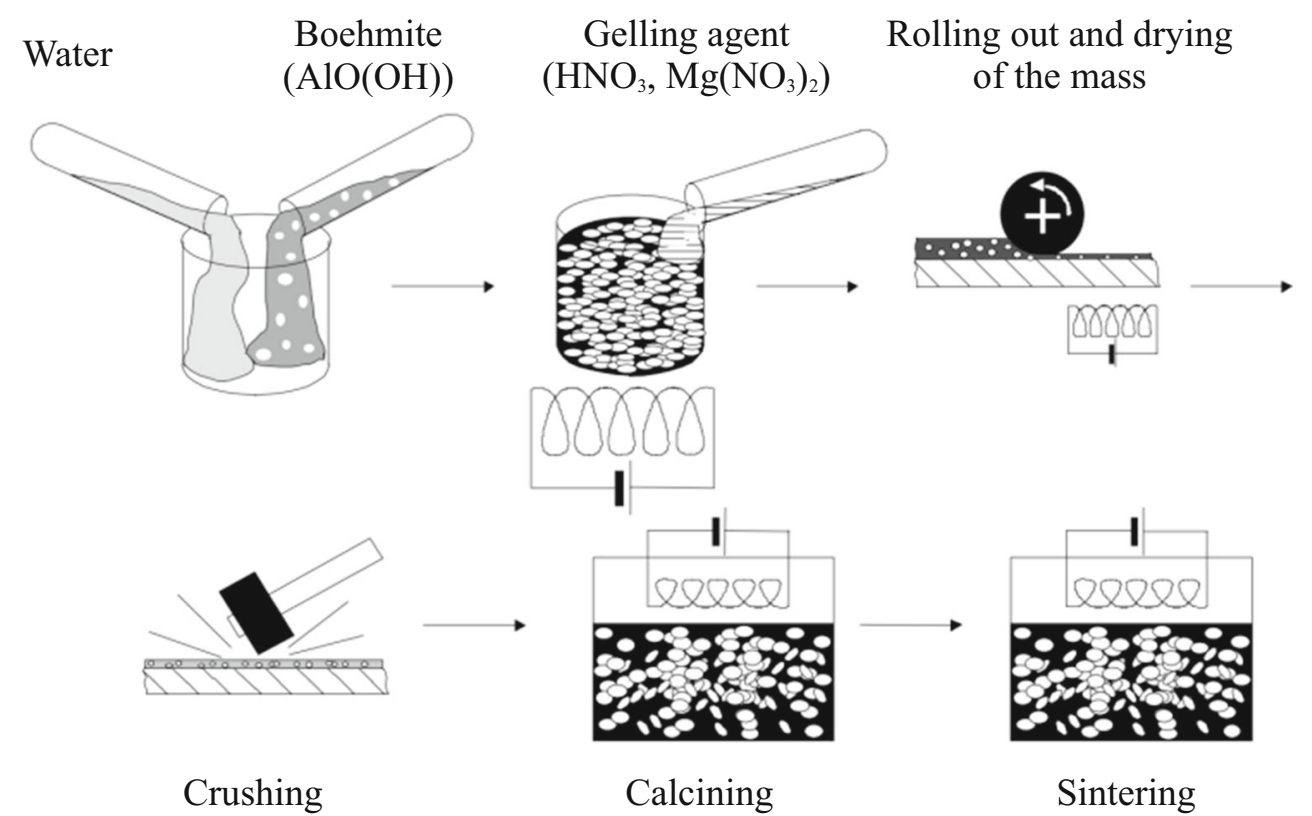


Fig. 6 Hardness and fracture toughness of abrasives and materials for cutting tools [34]

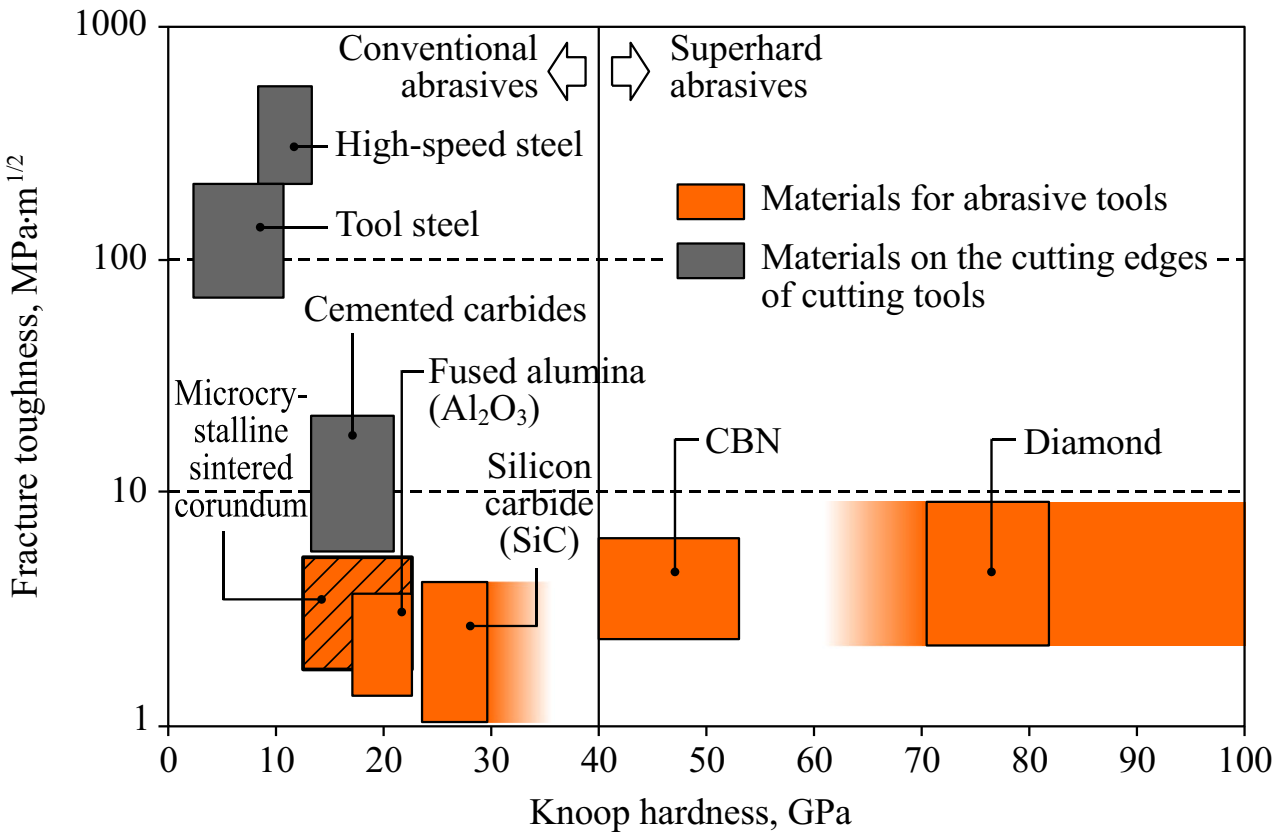

crystallographic layout) under the influence of strain. Such a process results in the loss of considerable grain mass, which is additionally enhanced by defects in the grain that cause microchipping. The dressing process also leads to dulling of the grinding wheel active surface through flattening of the grain corners. The reason for this is the fact that WFA grains are usually single crystallites [10, 20,34].

A microcrystalline sintered corundum grain has a submicrocrystalline structure, with particles sized $0,1-$ $5 \mu \mathrm{m}$ (however, usually $<1 \mu \mathrm{m}$ ). For reference, the size of sintered corundum crystallites is similar to the nominal grains size or slightly smaller. Such a structure results in the greater value of the critical stress intensity factor $K_{I c}$ of the grain. Proper selection of grinding and grinding wheel dressing parameters makes it possible for the phenomenon of abrasive grain self-sharpening to occur, which is caused by microparticles breaking out off of the grinding wheel, which causes the creation of sharp corners and cutting edges. As a result, it is possible to limit the grinding wheel wear through creation of a greater number of active apexes on its active surface [35].

Abrasive grains made from microcrystalline sintered corundum are more durable and maintain their shape longer than those made from white fused alumina. This is due to the fact that the working time between subsequent dresses can be prolonged by up to $80 \%$. Laboratory tests prove that the service life of such grinding wheels was 5 to 36 times greater [36] and, in some cases, even up to 70 times greater [37] than in the case of those with WFA. The machining efficiency obtained by grinding wheels with microcrystalline $\mathrm{Al}_{2} \mathrm{O}_{3}$ grains is far greater (even 10 times [37]).

In relation to $\mathrm{cBN}$, microcrystalline $\mathrm{Al}_{2} \mathrm{O}_{3}$ is up to 30 times cheaper and does not have such high requirements concerning

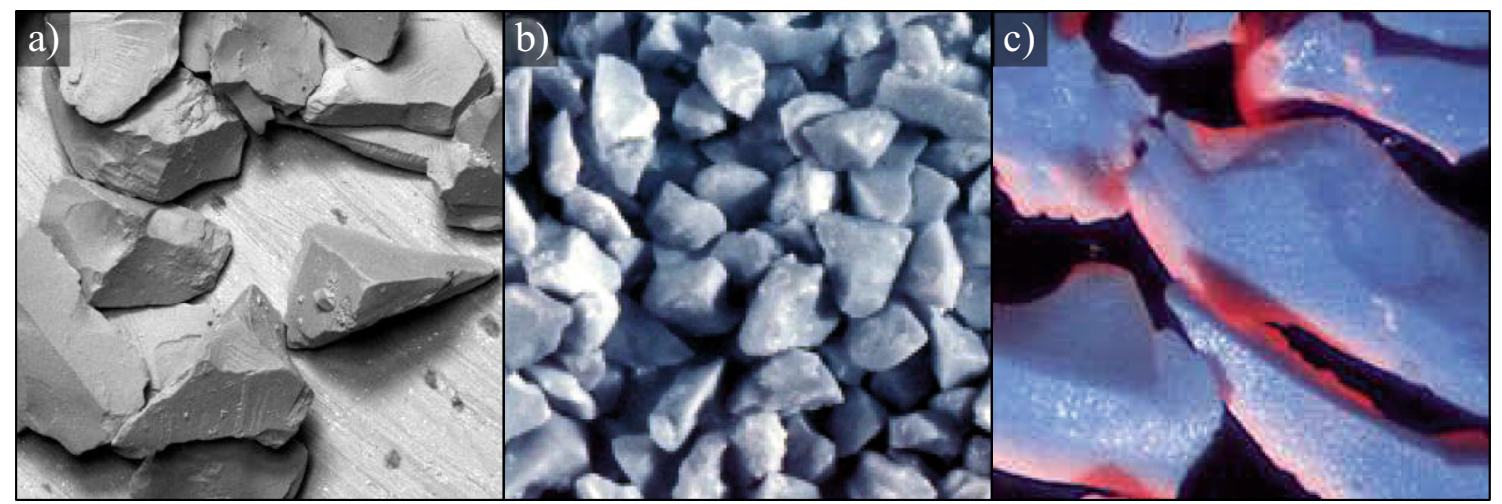

Fig. 7 View of the microcrystalline sintered corundum grains: a SGTM grains—magnification $\times 100$; b Cubitron $321^{\mathrm{TM}}-$ magnification $\times 50$ [16]; c Sapphire Blue ${ }^{\mathrm{TM}}$ grains - magnification approx. $\times 500$ [21] 
Fig. 8 Microscopic view of the $\mathrm{SG}^{\mathrm{TM}}$ grains microstructure: a magnification $\times 1,000$; b magnification $\times 10,000$

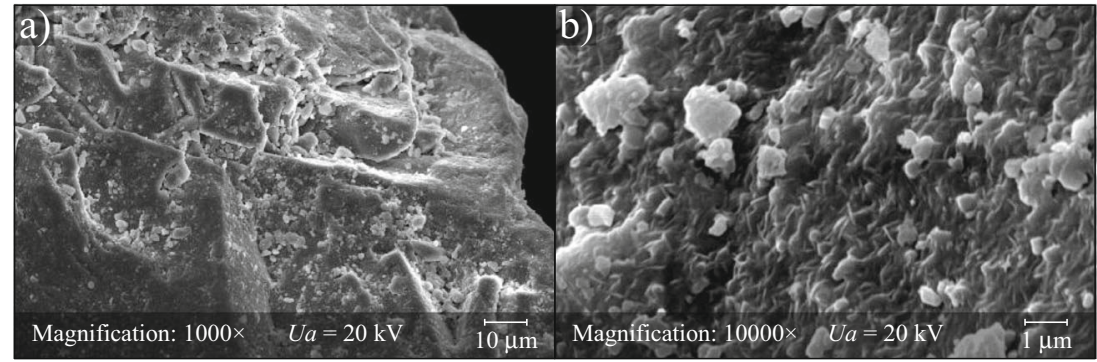

the grinding wheels. The conditioning (profiling, sharpening and cleaning) of grinding tools from microcrystalline sintered corundum resembles that of conventional grinding wheels. The cooling and lubrication systems face similar requirements. In order to make full use of abrasive tools from microcrystalline $\mathrm{Al}_{2} \mathrm{O}_{3}$, greater attention should be paid to the dressing procedure. The best results are obtained when rotating dressing tools are used. Stationary dressing tools are not completely disregarded, though microcrystalline diamond grains are preferable (MKD) [38, 39].

3.3 Working conditions and the phenomena of microcrystalline sintered grain wear

The efficiency of grinding with abrasive tools from various abrasive materials is highly dependent on the conditions in which the grains work and on the dominant wear processes, including the comprehensive system of phenomena that combine chipping, plastic deformations and chemical reactions $[40,41]$. The microfractures present in the abrasive develop into fracture systems when the strains reach their critical values, which leads to chipping of grain microfragments [42]. Microcrystalline alumina oxide grains can also be worn down as a result of plastic deformations, which result from the slippage and twinning of single crystallites [43, 44]. It was also proved that with a limited number of slippage systems, the grain wear intensity is highly dependent on the crystal orientation [45]. The process of plastic deformations of polycrystalline corundum is closely related to the crystal size and the level of strains [46, 47]. As the crystal size and load decreases, the grain deformation process changes from dominant slippage into diffusion creep and slippages along the crystal borders. However, the microcrystalline sintered corundum grain wear processes have not been examined sufficiently recently. The existent descriptions usually presented the advantages of grain crystal chipping and their selfsharpening through the uncovering of large numbers of new sharp corners. However, most works have skipped the interdependences between the chipping, plastic deformations, chemical reactions and diffusion that take place on the grain active apexes.

Table 1 Composition and properties of white fused alumina, microcrystalline sintered corundum and cubic boron nitride (cBN) abrasives [10, 20]

\begin{tabular}{|c|c|c|c|}
\hline & $\begin{array}{l}\text { White fused } \\
\text { alumina 99A }\end{array}$ & Microcrystalline sintered corundum & $\mathrm{cBN}$ \\
\hline Full name & Fused alumina $\mathrm{Al}_{2} \mathrm{O}_{3}$ & Microcrystalline sol-gel sintered alumina & Cubic boron nitride \\
\hline Chemical composition & $\begin{array}{l}\mathrm{Al}_{2} \mathrm{O}_{3} 99.7 \% \\
\mathrm{SiO}_{2} 0.01 \% \\
\mathrm{Fe}_{2} \mathrm{O}_{3} 0.02 \% \\
\mathrm{Na}_{2} \mathrm{O} 0.16 \% \\
\mathrm{CaO}+\mathrm{MgO} 0.02 \%\end{array}$ & $\begin{array}{l}\mathrm{Al}_{2} \mathrm{O}_{3} 95-99 \% \\
\mathrm{MgO} / \mathrm{Fe}_{2} \mathrm{O}_{3} 0-5 \%\end{array}$ & $\begin{array}{l}\sim 43.6 \% \mathrm{~B} \\
\sim 56.4 \% \mathrm{~N}\end{array}$ \\
\hline Crystal size & $\sim 10 \mu \mathrm{m}$ & $<1 \mu \mathrm{m}$ & $\begin{array}{c}\text { from } \sim 10 \mu \mathrm{m} \text { (monocrystalline) } \\
\text { to }<1 \mu \mathrm{m} \text { (microcrystalline) }\end{array}$ \\
\hline Shape & Pointed, sharp & Pointed, very sharp & $\begin{array}{l}\text { Block (hexagonal) or irregular, } \\
\text { very sharp }\end{array}$ \\
\hline Specific density & $3.96 \mathrm{~g} / \mathrm{cm}^{3}$ & $3.87 \mathrm{~g} / \mathrm{cm}^{3}$ & $3.48 \mathrm{~g} / \mathrm{cm}^{3}$ \\
\hline Knoop hardness HK & $20.3 \mathrm{GPa}$ & $21.5 \mathrm{GPa}$ & $42-54 \mathrm{GPa}$ \\
\hline Ductility & $2.0 \mathrm{MPa} \cdot \mathrm{m}^{1 / 2}$ & $3.7 \mathrm{MPa} \cdot \mathrm{m}^{1 / 2}$ & - \\
\hline The critical stress intensity factor $K_{I c}$ & $2.7 \mathrm{MPa} \cdot \mathrm{m}^{1 / 2}$ & $3.5-4.3 \mathrm{MPa} \cdot \mathrm{m}^{1 / 2}$ & $3.7 \mathrm{MPa} \cdot \mathrm{m}^{1 / 2}$ \\
\hline Coefficient of friction (hardened steel) & 0.34 & 0.19 & 0.19 \\
\hline Thermal conductivity coefficient $\lambda$ & $27-35 \mathrm{~W} / \mathrm{m} \cdot \mathrm{K}$ & $27-35 \mathrm{~W} / \mathrm{m} \cdot \mathrm{K}$ & $240-1,300 \mathrm{~W} / \mathrm{m} \cdot \mathrm{K}$ \\
\hline
\end{tabular}


Fig. 9 TEM cross-section of microcrystalline sintered corundum surface (a) with diffraction patterns obtained from the oxide layer (b) and plastically deformed layer (c) $[40,41]$

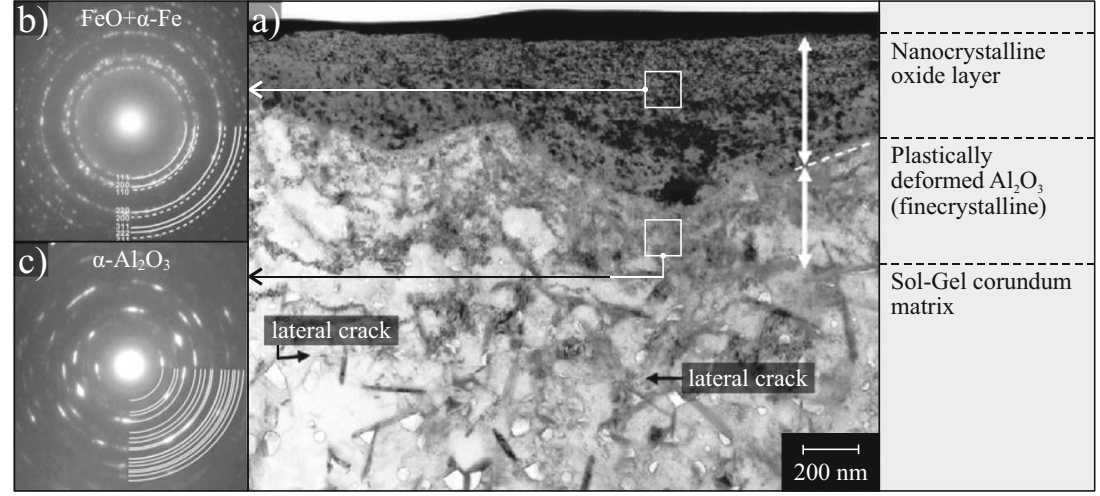

Works $[40,41]$ were the first ones to present in detail the processes of grinding and wear of $\mathrm{Al}_{2} \mathrm{O}_{3}$ grains with microcrystalline structure. They prove that the excellent cutting capacity of these grains is closely connected with the tribological properties of the smoothed out surfaces of cutting apexes in the zone of contact with the machined material. Under the influence of strain and temperature, the abrasive microcrystalline sintered corundum grain apexes are plastically deformed, thus creating flat surfaces of contact with the machined material. The contact between the abrasive grain apex and the machined material causes the dispersion of a large amount of energy and a local temperature rise, which melts the thin surface layer. The alloy consists of a phase with a decreased melting temperature, which, in the case of steel $100 \mathrm{Cr} 6$, results in the creation of iron oxide $\mathrm{FeO}$ and a liquid phase with high cohesiveness (Figs. 9 and 10). This considerably decreases both wear and friction in the contact zone.

Catastrophic chipping of larger grain fragments stops at the microcrystalline borders, as a result of which the cracks remain close to the surface and do not propagate deep into the grain, as in the case of polycrystalline $\mathrm{Al}_{2} \mathrm{O}_{3}$ grains. The excellent cutting capacity of the microcrystalline grains can also be explained by the stable slippage conditions on the grain flat surfaces, created behind the cutting edges. As a result, microcrystalline sintered corundum makes it possible to increase the grinding efficiency with limited abrasive grain wear $[40,41]$.

The results of the author's own research confirm such a model of microcrystalline sintered corundum grain wear.

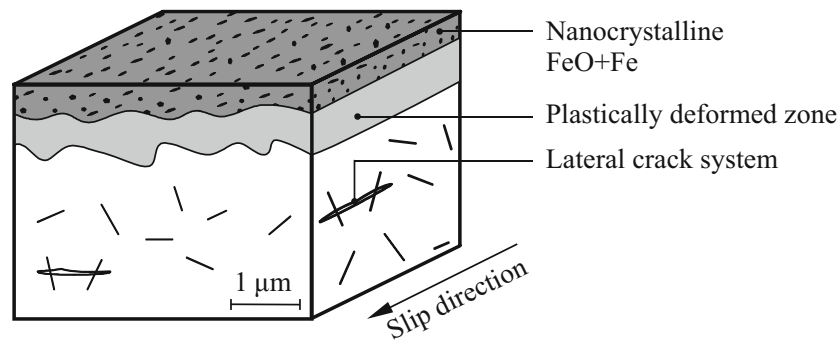

Fig. 10 Schematic illustration of the structure of the smoothed surface of microcrystalline sintered corundum [40]
The following results were obtained on the universal grinder RUP 28P made by Mechanical Works Tarnow SA (Poland) equipped with a spindle-type EV-70/70-2WB produced by Fisher, Switzerland (maximum $\mathrm{rpm} 60,000 / \mathrm{min}$, power of machine cutting $5.2 \mathrm{~kW}$ ) and shown in Fig. 11.

Selected results of the internal cylindrical plunge grinding with oscillations of $100 \mathrm{Cr} 6$ steel, using a grinding wheel with microcrystalline sintered corundum grains, were given in Fig. 12. Changes in the value of the analyzed parameters indicates the stable operation of the test wheel over a long period of time whilst obtaining the assumed quality of the workpiece surface $(R a<0.63 \mu \mathrm{m})$.

Figure 13 shows SEM views of the grinding wheel active surface with microcrystalline sintered corundum grains after 100 min of internal cylindrical plunge grinding with oscillations of $100 \mathrm{Cr} 6$ steel.

The conducted analyses, performed during the research, on various types of cylindrical grinding (reciprocal, plunge and traverse internal cylindrical grinding) showed that the dominant microcrystalline active abrasive grain apex wear phenomenon is the creation of flat surfaces as a result of their

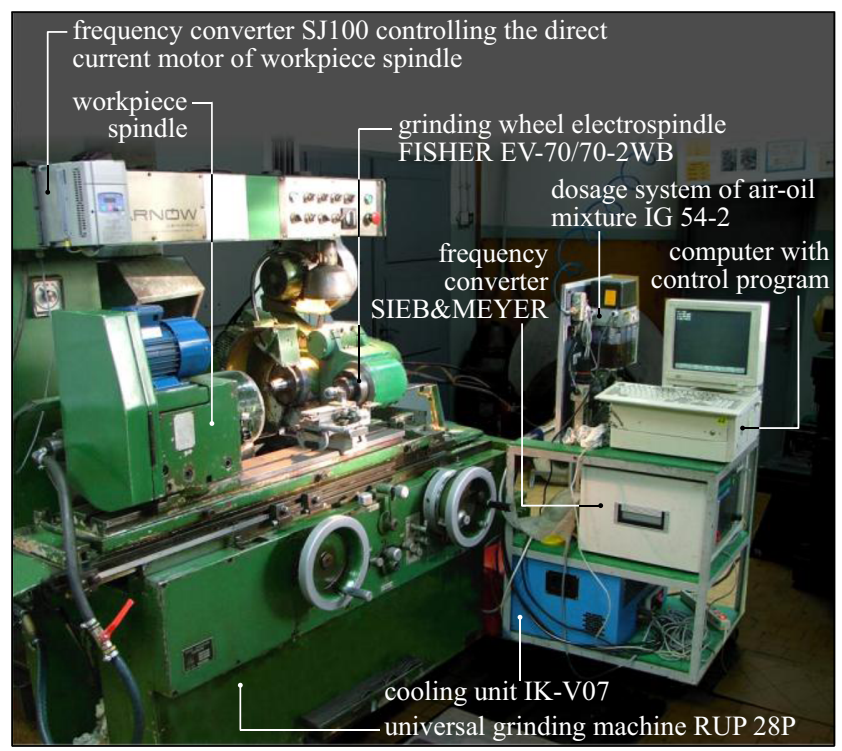

Fig. 11 General view of the experimental setup 
Fig. 12 Selected results of the internal cylindrical plunge grinding with oscillations of $100 \mathrm{Cr} 6$ steel using a grinding wheel with microcrystalline sintered corundum grains: a arithmetic mean deviation of the workpiece roughness profile $R a$; b grinding power gain $\Delta P$; c maximum roundness deviation of the grinding wheel $\Delta$; d circumference profile of the grinding wheel after dressing; e circumference profile of the grinding wheel after grinding tests (rms root-mean-square roundness deviation from mean circle, $v_{s}$ grinding wheel peripheral speed, $a_{e}$ working engagement/ machining allowance, $v_{f a}$ axial table feed speed, $v_{f r}$ radial table feed speed, $Q_{c}$ grinding fluid flow rate, $V_{w}$ material removal, $G$ grinding indicator)

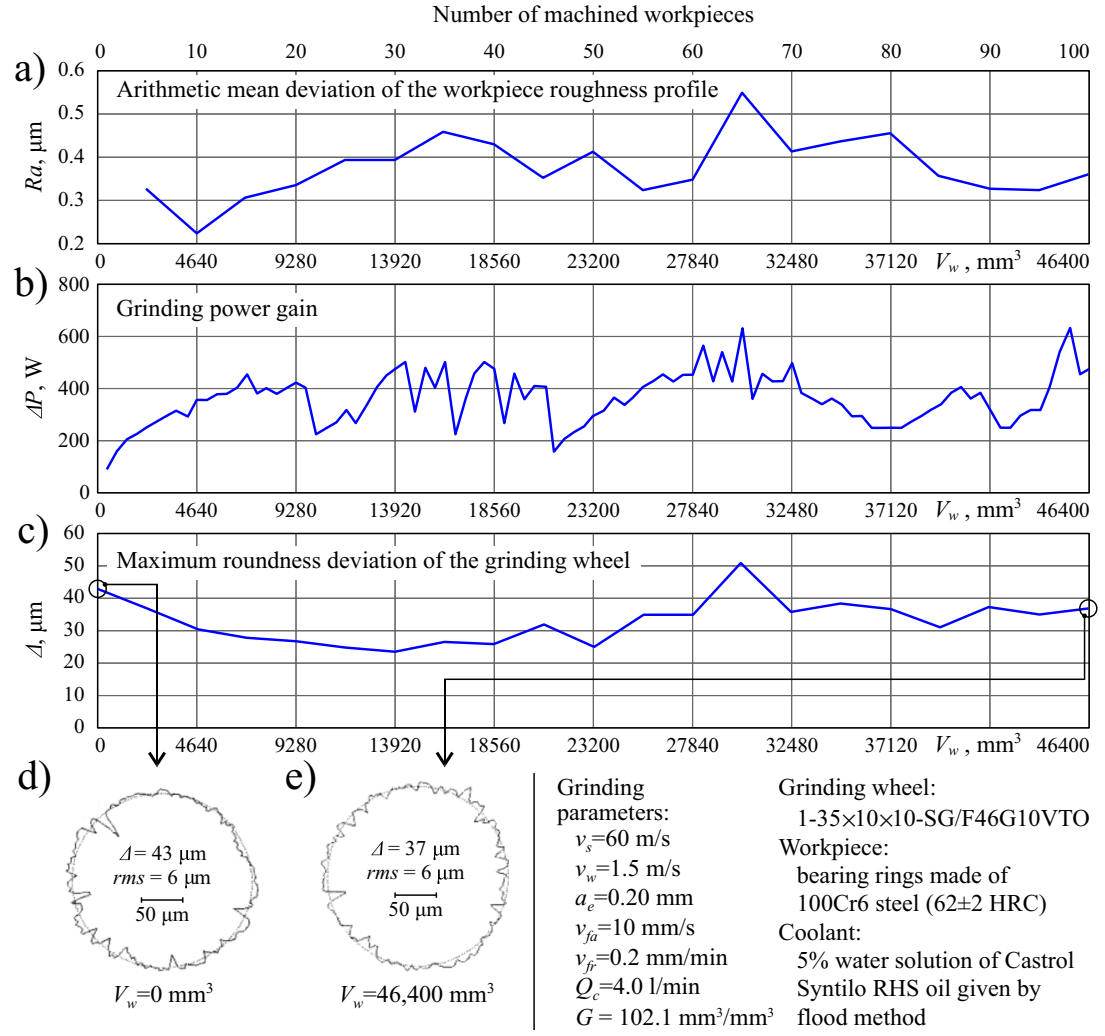

plastic flow (Fig. 13a) [48]. This phenomenon was common on the grinding wheel active surfaces and did not exert a negative influence on the obtained removal rate or the quality of the machined surface.

It was also observed that the phenomenon of the oxide layer shedding and the plastically deformed grain layer occurs periodically on the smoothed out surfaces of the active apexes. This process is caused by fatigue and thermo-fatigue wear, as a result of which sharp edges of crystals located below the plastically deformed surface layer are uncovered (Fig. 13b).

To sum up, the processes of poly- and microcrystalline alumina oxide grains wear processes can be compared, as presented in Fig. 14.
In the case of fused alumina with a polycrystalline structure (e.g. WFA 99A), depending on the grain load, whole or large parts of abrasive grains, may be chipped out as a result of easy propagation of fractures along the crystallographic borders of large-sized grains. Small surfaces of grain are also smoothed out, which is caused by plastic flow at high temperatures (Fig. 14a).

Whilst in the case of microcrystalline grains, the chippings usually occur only in microcrystals, with the large surfaces of grain apexes becoming smoothed out and the surface layer getting periodically peeled off, revealing the sharp edges of the crystals located further under the surface (Fig. 14b). The processes of microcrystalline sintered grains being worn down
Fig. 13 SEM views of the grinding wheel active surface with microcrystalline sintered corundum grains after internal cylindrical plunge grinding with oscillations of $100 \mathrm{Cr} 6$ steel: a smoothed grain vertexes; b exfoliation of plastically deformed top layer of the grain

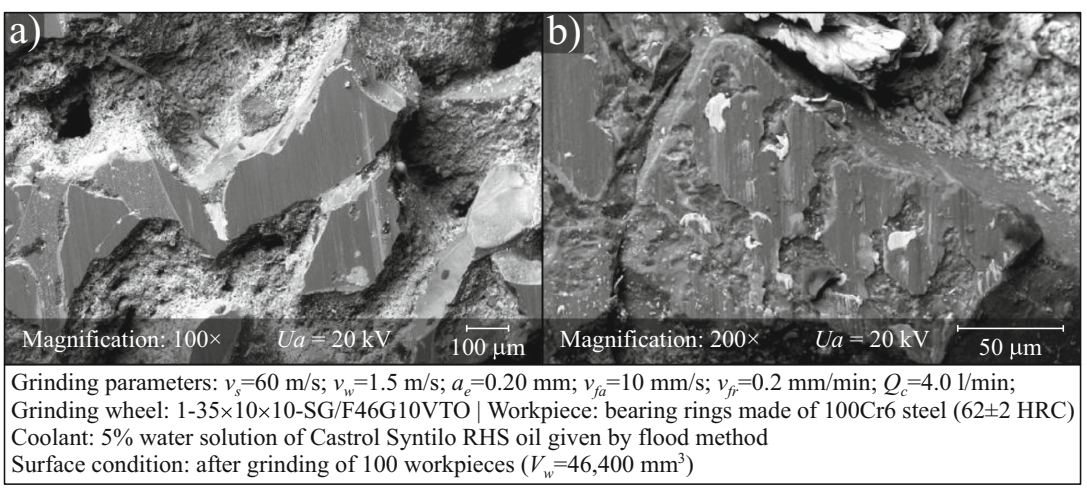


are captured in a series of microscopic SEM images registered on the active surface of the grinding wheel with $\mathrm{SG}^{\mathrm{TM}}$ grains after internal cylindrical grinding in steel $100 \mathrm{Cr} 6$. These images are presented in Fig. 14c.

In macro-scale, using grinding wheels with microcrystalline sintered corundum does not create additional requirements in relation to other tools made from conventional abrasives. Both the selection of the process parameters as well as grinding conditions (forces, temperature, etc.) are similar to grinding processes conducted using other abrasives based on $\mathrm{Al}_{2} \mathrm{O}_{3}$. The main advantage of grains with microcrystalline structure is the possibility they offer of extending the period between dressing cuts (extending tool life), as well as increasing the material removal rate and reducing the risk of defects caused by grinding wheel wear [10, 20, 34].

\section{Microcrystalline sintered corundum with an elongated shape}

The next step in the development of grinding technology, related to microcrystalline sintered corundum grains, was the creation of varieties of extruded and sintered grains characterized by an elongated shape. An example of this is the TG ${ }^{\mathrm{TM}}$ abrasive presented by the Norton company in 1993, and a)

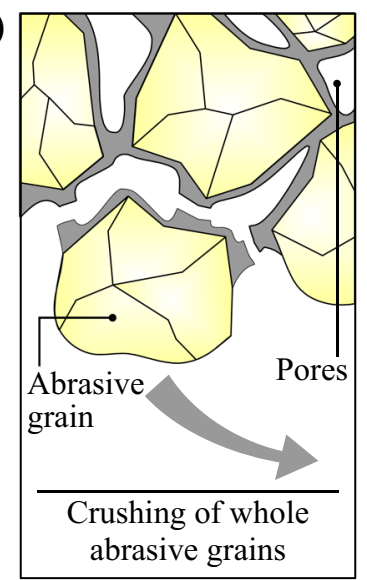

b)

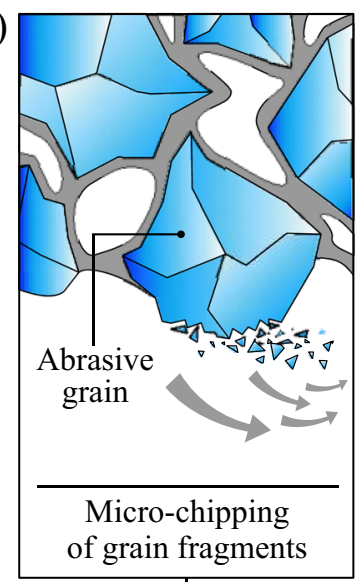

c)

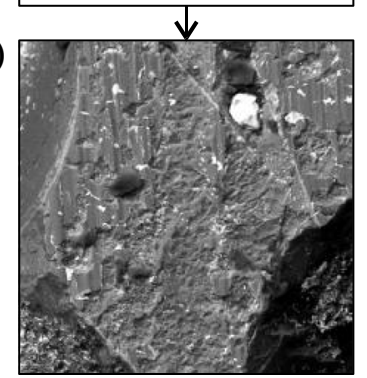

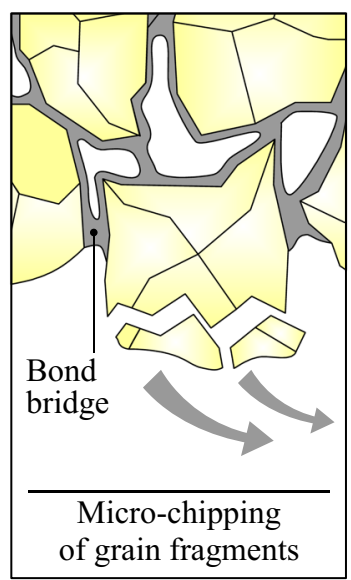
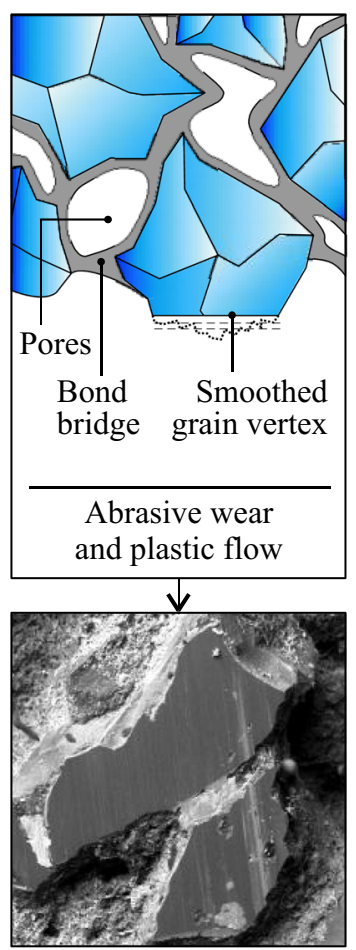
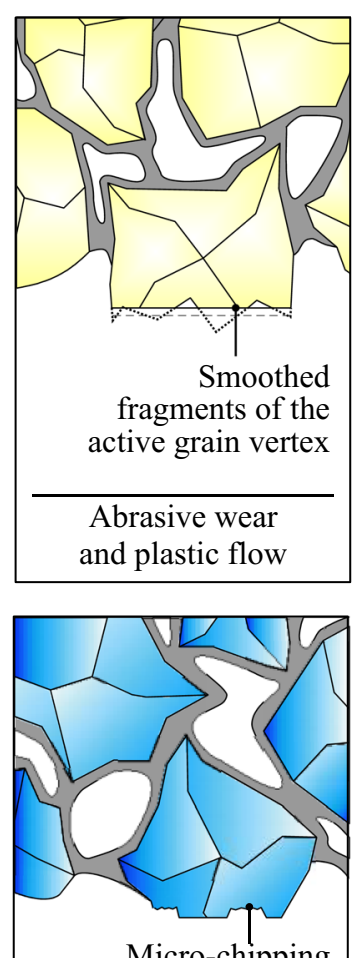

Micro-chipping plastically deformed and exfoliation of the grain layer

Fatigue and thermo-fatigue wear

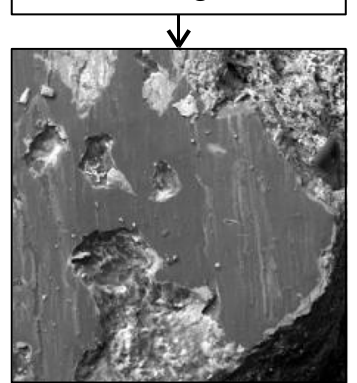

Polycrystalline structure abrasive grains (eg. white fused alumina 99A)

Microcrystalline structure abrasive grains (eg. microcrystalline sintered corundum $\mathrm{SG}^{\mathrm{TM}}$ )

Microscopic images of the wear form of the microcrystalline sintered corundum abrasive grains

Fig. 14 Grain breakdown models in grinding wheels with polycrystalline (a) and microcrystalline (b, c) alumina abrasives (based upon drawings of the Rappold Winterthur Group and the author's own materials) 


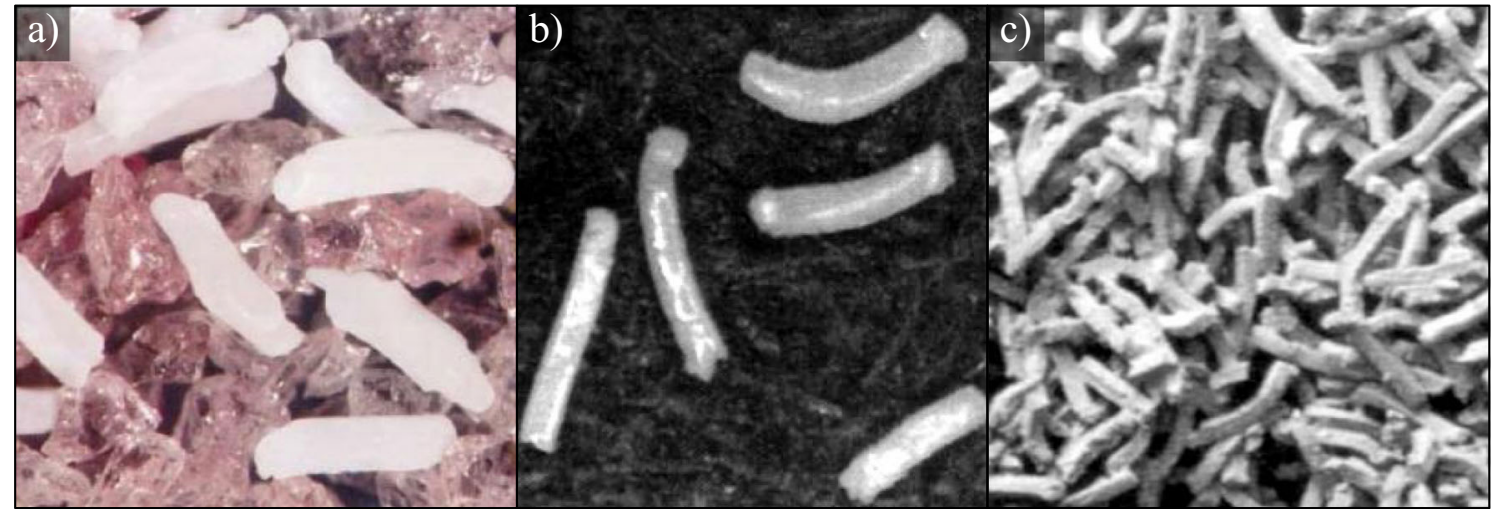

Fig. 15 View of the microcrystalline sintered corundum grains with elongate shape: a TG ${ }^{\mathrm{TM}}$ grains with dimension proportion 4:1 mixed with CrA grains; b TG2 ${ }^{\mathrm{TM}}$ grains with shape proportion 8:1; $\mathbf{c}$ Norton's Altos ${ }^{\mathrm{TM}}$ wheel structure with TG2 ${ }^{\mathrm{TM}}$ grains $[49,50]$

characterized by the relation of length to the maximum lateral size 4:1 (Fig. 15a) or grains with proportion 8:1 (Fig. 15b) marked as TG2 ${ }^{\mathrm{TM}}[49,50]$.

In 1995, the same concern presented a hybrid abrasive, a mixture of chrome fused alumina (CrA) and sintered grains of $\mathrm{TG}^{\mathrm{TM}}$ type under the trade name TGP ${ }^{\mathrm{TM}}$. The aim of creating such abrasive materials was to equip them with particular properties that would meet the abrasive machining conditions, i.e. greater precision and increased material removal efficiency resulting in the improved quality of the machined surface. In seeking to increase the efficiency of grinding with grains of elongated shape, there is a tendency towards the regular layout and optimum grain orientation of such grains within the grinding wheel volume. Microcrystalline sintered corundum grains with elongated shape make it possible to create tools with a very open structure (Fig. 15c), which facilitates the liquid coolant reaching the grinding zone. In particular, applications, e.g. in grinding hard-to-cut materials such as Inconel ${ }^{\circledR}$ or Rene ${ }^{\circledR}$, the hardness, size and coolant capacity make it possible to obtain a cutting capacity that exceeds the CBN grains by an order of magnitude [8].

\section{Nanocrystalline sintered corundum}

The development of microcrystalline sintered corundum grains obtained using the sol-gel technology is heading towards obtaining structure with smaller crystals. In 2008, the
Norton company introduced Quantum ${ }^{\mathrm{TM}}$ grinding wheels with new generation microcrystalline sintered corundum grains, marked $\mathrm{NQ}^{\mathrm{TM}}$ [51]. This abrasive is characterized by far smaller crystallites in comparison with $\mathrm{SG}^{\mathrm{TM}}$ grains (Fig. 16). However, this is still not enough for the crystals to be labelled nano.

It was only in 2008 when the first reports appeared about abrasive grains from nanocrystalline sintered corundum whose average grain size was below $100 \mathrm{~nm}$ [52-54] (60 nm [55]), which is produced with the sol-gel technology using the two-level sintering method in $1,150-1,300{ }^{\circ} \mathrm{C}$ [52-54]. The grain growth is considerably limited through sintering temperature control and the application of compounds supporting sintering such as $\mathrm{MgO}-\mathrm{CaO}-\mathrm{SiO}_{2}$, during the last of the twolevel sintering stages. Material of high-density (over $99 \%$ of the theoretic density), characterized by grain sizes approximately 10 times smaller than is the case during traditional sintering processes, is obtained as a result of such processes [54]. The microstructure of nanocrystalline sintered corundum grains obtained with this method is uniform and devoid of excessively developed crystals, as presented in Fig. 17.

The technology of obtaining such grains is still developing and aims at obtaining ever greater crystal density, limiting their size and decreasing the sintering temperature [56].

The application of abrasive grains that possess a nanocrystalline structure in grinding aims to enable a change in the wear mechanism of the grain from the micro- to the nanoscale.
Fig. 16 Comparison of the microstructure of the sintered corundum grains type $\mathrm{SG}^{\mathrm{TM}}(\mathbf{a})$ and type $\mathrm{NQ}^{\mathrm{TM}}(\mathbf{b})$ which are used in the Quantum ${ }^{\mathrm{TM}}$ grinding wheels by Norton [51]

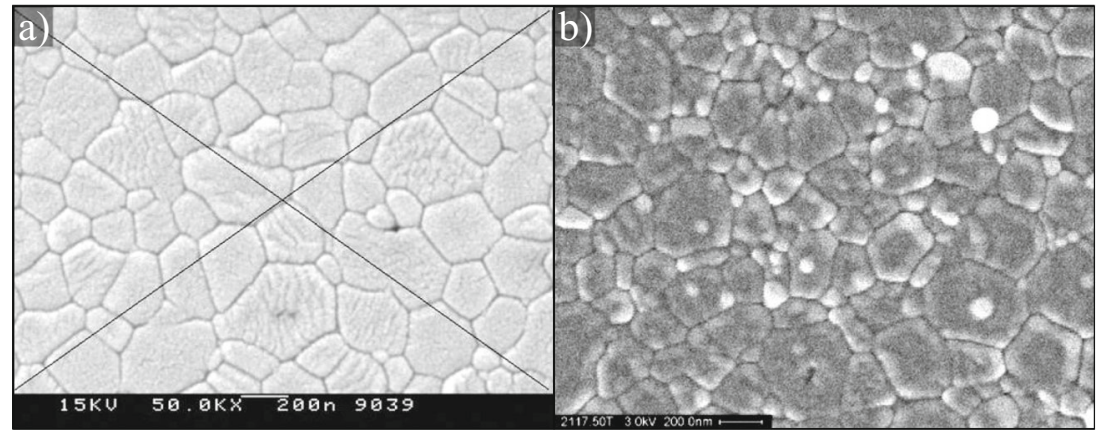


Fig. 17 Microscopic view of the nanocrystalline sintered corundum microstructure: a magnification $\times 40,000[53]$; b magnification $\times 125,000$ [54]

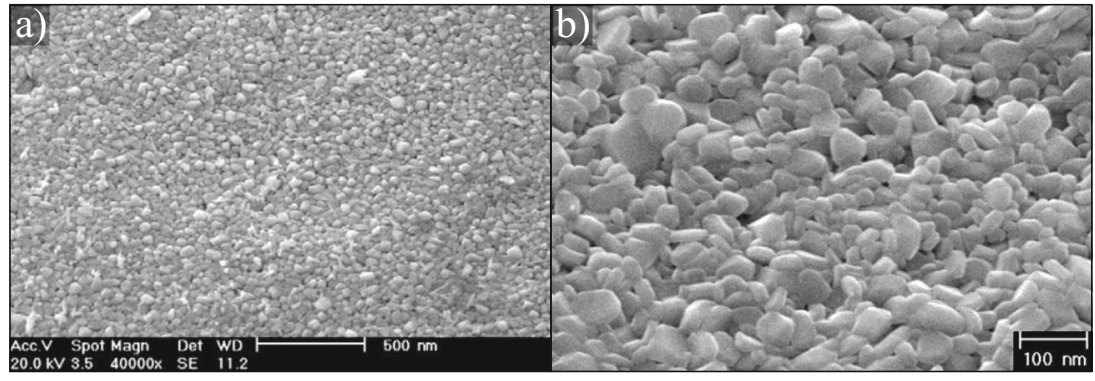

Nanocrystalline structure would allow for nano-crushing of the dulled abrasive grains surface, as well as their regeneration (sharpening). It can therefore be expected to significantly extend the life of tools made from this type of abrasive grain within the grinding processes. An important factor is also the possibility of increasing the grains toughness as a result of its fine crystalline structure.

\section{Applications of microcrystalline sintered corundum abrasive grains}

Abrasive tools made from microcrystalline sintered corundum are used during processes for grinding tool steels, bearing ring steels and nickel superalloys (e.g. Inconel ${ }^{\circledR}$, Incoloy ${ }^{\mathbb{R}}$, etc.). These grinding wheels are used in grinding processes in which precise machining should be accompanied by optimization of productivity and machining costs. These processes include, among others, surface grinding and cylindrical grinding, as well as grinding flutes on cutting tools [57]. These abrasive grains are widely used in almost all grinding options (either dry or using coolants), using iron and non-iron materials with a hardness 30-67 HRC [10].

The most important application areas of microcrystalline sintered corundum abrasive grains are given in Table 2 .

\section{Summary}

This paper presented the current state of knowledge regarding production technology, properties, working conditions, wear phenomena and applications of microcrystalline corundum grains. This enabled the following conclusions to be drawn:

- The main group of abrasives currently produced and utilised are now conventional abrasive grains based on $\mathrm{Al}_{2} \mathrm{O}_{3}$ and $\mathrm{SiC}$,

- Among the abrasives based on $\mathrm{Al}_{2} \mathrm{O}_{3}$, microcrystalline sintered corundum grains have become ever more important. This is due to the unique advantages resulting from their microstructure, such as the following: relatively higher toughness and ductility as well as higher critical stress intensity factor $K_{I c}$,

- The ability to extend the life of tools made with microcrystalline sintered corundum abrasive grains are strongly influenced by the specific phenomena occurring in microareas on the active grain vertexes,

- The current range of applications of these grains, within the field of grinding technology, is very broad and includes, among others, the following: grinding of steel, non-ferrous metals, wood and plastics.

It is estimated that in the future, abrasives formed from micro- and nanocrystalline alumina oxide, and new ones

Table 2 Application areas of microcrystalline sintered corundum abrasive grains [10]

\begin{tabular}{lll}
\hline Range of applications & Grinding process & Materials \\
\hline - Grinding wheels (mostly with ceramic bond) & - External grinding & - Unalloyed \\
- Grinding belts & - Internal grinding & - Alloyed \\
& - Centreless grinding & - Untempered \\
& - Surface grinding & - Tempered steels up to 63 HRC \\
& - Profile grinding & - Specially tempered steel more than 63 HRC \\
& - Thread grinding & - Tool steel \\
& - Tool grinding & - High speed steel \\
& - Gear flank grinding & - Casting \\
& - High performance belt grinding & - Non-ferrous metals \\
\hline
\end{tabular}


obtained in chemical precipitation or sintering processes, will dominate the market for conventional abrasive grains. This is also connected with a drop in the prices of these abrasives, which is as a result of their increased production in developing countries, such as China or Brazil [11]. At present, the price of microcrystalline sintered corundum is approximately $2-3$ times higher than that of their fused alumina counterparts $[38,39]$. Taking into consideration the considerably greater cutting capacity and resistance to wear of the microcrystalline sintered corundum, it is more than likely that it will be systematically popularized in relation to the processes of precise abrasive assisted machining.

Open Access This article is distributed under the terms of the Creative Commons Attribution License which permits any use, distribution, and reproduction in any medium, provided the original author(s) and the source are credited.

\section{References}

1. Nadolny K (2012) The effect of integrating the structural modifications of the grinding wheel upon the internal cylindrical grinding process. Arch Civ Mech Eng 12:60-67

2. Nadolny K (2013) A review on single-pass grinding processes. J Cent South Univ 20:1502-1509

3. Nadolny K (2013) Microdiscontinuities of the grinding wheel and their effects on its durability during internal cylindrical grinding. Mach Sci Technol 17:74-92

4. Herman D, Plichta J, Nadolny K (2006) New ceramic abrasive tools for rough and finishing grinding in one pass. Mater Sci Forum 526: $163-168$

5. Slowinski B, Nadolny K (2007) Effective manufacturing method for automated inside diameter grinding. J Adv Mech Des Syst Manuf 1: 472-480

6. Kane TM (2009) Global markets and applications of superabrasive materials. http://superabrasives.org/members/membersonly/ marketstudies/2009GlobalMarketsand Applications ofSuperabrasiveMaterials.pdf. Accessed 26 January 2012

7. U.S. Geological Survey (2012) Mineral commodity summaries, abrasives (manufactured)

8. Jackson MJ, Davim JP (2010) Machining with abrasives. Springer, New York

9. Klocke F (2000) Mikrokristallines Aluminiumoxid macht CBN Konkurenz, Wirtschaftlich mit hohem Zerspanungsvolumen. Ind Anz 122:49-50

10. Klocke F (2009) Manufacturing processes 2: grinding, honing, lapping. Springler-Verlag, Berlin

11. Marinescu ID, Hitchiner M, Uhlmann E, Rowe WB, Inasaki I (2007) Handbook of machining with grinding wheels. CRC Press, Boca Raton

12. Marinescu ID, Rowe WB, Dimitrov B, Inasaki I (2004) Tribology of abrasive machining processes. William Andrew Inc., Norwich

13. Backus R (2007) Uphill struggle. Ind Min 12:32-38

14. Doral Fused Materials Pty Ltd (2012) White fused alumina application. http://www.afm.com.au/view/products/\#white. Accessed 14 January 2012

15. BBC Research (2001) Abrasive products: materials, applications and markets

16. $3 \mathrm{M}$ company (2006) $3 \mathrm{M}$ Cubitron ${ }^{\mathrm{TM}}$ abrasive grain brochure
17. Bange DW (1998) Sol-gel abrasive makes headway. Tool Prod 63: $82-84$

18. Holland T (1994) Don't be scared off higher-tech grinding. Metalwork Prod 138:48

19. Meister M, Meister T (1995) Diamant, CBN und Sinterkorundmoderne Schleifmittel: Herausforderungen für die Zukunft, Schweiz. Maschinenmarkt 17:38-43

20. Rowe WB (2009) Principles of modern grinding technology. William Andrew, Burlington

21. Sapphire Blue ${ }^{\circledR}$ Ceramic Grain (2012) http://www.hermesabrasives. com/info/sapphireblue.html. Accessed 14 January 2012

22. Tönshoff HK, Karpuschewski B, Mandrysch T, Inasaki I (1998) Grinding process achievements and consequences on machine tools challenges and opportunities. CIRPAnn-Manuf Technol 47:651-668

23. Ueltz HFG (1963) Abrasive grain. U.S. Patent No. 3079243

24. Nizankowski C (2002) Manufacturing sintered corundum abradants. Arch Civ Mech Eng 2:53-64

25. Baumann S, Maier HR, Engelhorn R, Klocke F (2003) Sol-GelKorunde für die Schleifbearbeitung, Teil 1. Keram Z 55:496-499

26. Baumann S, Maier HR, Engelhorn R, Klocke F (2003) Sol-GelKorunde für die Schleifbearbeitung, Teil 2. Keram Z 55:606-609

27. Ludewig $T$ (1994) Auswahlkriterien für SiC-und Korundschleifkorntypen beim Schleifen von Stählen. Dissertation, RWTH Aachen

28. Stark C (1997) Leistungsvermögen und Potentiale verschleißfester Schleifmittel auf Unterlage. Schleiftechnik im Wettbewerb. VDI Verlag GmbH, Düsseldorf

29. Uhlmann E (1996) Entwicklungsstand von Hochleistungswerkzeugen mit mikrokristalliner Aluminiumoxidkörnung. Vortrag zum 8. Int. Braun-schweiger Feinbearbeitungskolloquium

30. Cottringer TE, Van de Merve RH, Bauer R (1986) Abrasive material and method for preparing the same. U.S. Patent No. 4623364

31. FEPA-Standard 42-1:2006 Grains of fused aluminium oxide, silicon carbide and other abrasive materials for bonded abrasives and for general applications. Macrogrits F 4 to F 220

32. ISO 8486-1:1996 Bonded abrasives - determination and designation of grain size distribution - part 1: macrogrits F4 to F220

33. ISO 8486-2:2007 Bonded abrasives - Determination and designation of grain size distribution - Part 2: Microgrits F230 to F2000

34. Helletsberger H, Noichl J (1993) Einsatzbereiche von Schleifstoffen. Grenzwerte und Wirtschaftlichkeit von Korund, Sinterkorund und CBN. Tech Rundsch 85(13):24-28

35. Matsuo T (1993) Recent researches on high efficiency and heavy duty grinding. Int J Jpn Soc Precis Eng 27:303-306

36. Jones R (1996) Getting to grips with grinding. Metalwork Prod 140(9):31-34

37. Merkel P (1991) Zwischen Korund und CBN. Viel mehr Schneiden pro Schleifkorn. Ind Anz 113(7):10-12

38. Grinding wheel and abrasives basics (2012) http://www. georgiagrindingwheel.com/grindingwheels_basics.htm. Accessed 20 January 2012

39. Narbut N, Stafford T, Tartaglione J (2012) Grinding with segments. Cutting tool engineering. http://www.ctemag.com/dynamic.articles. php?id=101. Accessed 20 January 2012

40. Klocke F, Engelhorn R, Mayer J, Weirich T (2002) Microanalysis of the contact zone of tribologically loaded secondphase reinforced sol-gel-abrasives. CIRP Ann-Manuf Technol 51:245-250

41. Mayer J, Engelhorn R, Bot R, Weirich T, Herwartz C, Klocke F (2006) Wear characteristics of second-phase-reinforced sol-gel corundum abrasives. Acta Mater 54:3605-3615

42. Evans AG (1979) Science of ceramic machining and surface finishing II. US Government Printing Office, Washington

43. Kronberg ML (1957) Plastic deformation of single crystals of sapphire: basal slip and twinning. Acta Metall 5:507-524 
44. Steijn RP (1961) On the wear of sapphire. J Appl Physiol 32:19511959

45. Duwell EJ (1962) Friction and wear of single-crystal sapphire sliding on steel. J Appl Physiol 33:2691-2699

46. Cannon RM, Rhodes WH, Heuer AH (1980) Plastic deformation of fine-grained alumina $\left(\mathrm{Al}_{2} \mathrm{O}_{3}\right)$ : I, interface-controlled diffusional creep. J Am Ceram Soc 63:46-53

47. Heuer AH, Tighe NJ, Cannon RM (1980) Plastic deformation of finegrained alumina $\left(\mathrm{Al}_{2} \mathrm{O}_{3}\right)$ : II, basal slip and nonaccommodated grainboundary sliding. J Am Ceram Soc 63:53-61

48. Nadolny K, Slowinski B (2011) The effects of wear upon the axial profile of a grinding wheel in the construction of innovative grinding wheels for internal cylindrical grinding. Adv Tribol. doi:10.1155/ 2011/516202

49. Norton company (1999) Project Altos brochure

50. Norton company (1999) Project Optimos - Grind in the fast line brochure

51. Korn D (2011) Reducing fastener grinding costs using advanced abrasives. Mod Mach Shop 11(11)
52. Li Z-C, Li Z-H, Zhang A-J, Zhu Y-M (2008) Synthesis processes of nano alumina abrasive. Key Eng Mater 368-372:691-693

53. Li Z-C, Li Z-H, Zhang A-J, Zhu Y-M (2009) Influence of thermal treatment conditions on two-dimensional crystal growth of nanocrystal corundum abrasives. Mater Res Bull 44:762-767

54. Li Z-C, Li Z-H, Zhang A-J, Zhu Y-M (2009) Synthesis and two-step sintering behavior of sol-gel derived nanocrystalline corundum abrasives. J Eur Ceram Soc 29:1337-1345

55. Li Z-C, Li Z-H, Zhang A-J, Zhu Y-M (2009) Synergistic effect of $\alpha-\mathrm{Al}_{2} \mathrm{O}_{3}$ and $\left(\mathrm{NH}_{4}\right)_{3} \mathrm{AlF}_{6}$ co-doped seed on phase transformation, microstructure, and mechanical properties of nanocrystalline alumina abrasive. J Alloys Compd 476:276-281

56. Li Z-C, Zhang A-J, Li Z-H, Zhu Y-M, Liu L-J, Xiang H (2011) A novel low temperature synthesis technique of sol-gel derived nanocrystalline alumina abrasive. J Sol-Gel Sci Technol 57:24-30

57. Heuer W (1990) Gesintertes Aluminiumoxid — ein neuer Schleifstoff zum Innenrundschleifen. Wirtschaftliche Alternative. Ind Anz 112(69):44-46 